\title{
High-Voltage Safety Improvement Design for Electric Vehicle in Rear Impact
}

\author{
Yubo Lian ${ }^{1} \cdot$ Dong Zeng ${ }^{1} \cdot$ Sheng $\mathrm{Ye}^{1} \cdot$ Binggen Zhao $^{1} \cdot$ Haizhang Wei $^{1}$
}

Received: 28 May 2018 / Accepted: 31 July 2018 / Published online: 20 August 2018

(c) The Author(s) 2018

\begin{abstract}
High voltage safety is very important for electric vehicles, how to ensure the passengers' safety in traffic accidents is an important research subject. This paper describes a study of the high-voltage safety of an electric vehicle under rear impact conditions to ensure that it is in accordance with Chinese regulations. The high-voltage safety has been analyzed and optimized from several perspectives and includes the development of a high-voltage cutoff strategy, assessment of the integrity of the high-voltage components after the crash, the layout of the high-voltage and low-voltage cables, and the crashworthiness of the structure. This study resolved the high-voltage safety problems that were found in the design phase and thus ensured that the vehicle not only meets the requirements of the Chinese regulations, but also meets the high-voltage safety requirements of US Federal Motor Vehicle Safety Standard (FMVSS) 305 for $80 \mathrm{~km} / \mathrm{h}$ rear impact.
\end{abstract}

Keywords Electric vehicle $\cdot$ Rear impact $\cdot$ High-voltage safety $\cdot$ Optimization

\section{Introduction}

The manufacturing output of automobiles in China was nearly 28 million vehicles in 2016 and reached nearly 31 million in 2017. The Chinese automobile industry has become a principal support industry for economics. Demand for petroleum in China has increased by more than 50\% and is likely to increase further in the future [1]. With the increasing manufacturing output and the existing numbers of automobiles, the automobile industry will bring convenience for personal travel while simultaneously producing

Sheng Ye

yes2012ncu@sina.com; gongchengyuan@byd.com;

ye.sheng@byd.com

Yubo Lian

lian.yubo@byd.com

Dong Zeng

zengdong190@163.com

Binggen Zhao

zhao.binggen@byd.com

Haizhang Wei

wei.haizhang@byd.com

1 BYD Automotive Engineering Research Institute, Hexagon Building, No. 3009 of BYD Road, Pingshan,

Shenzhen 518118, China three problems, in the form of increased oil consumption, safety concerns and increased emissions [2-4].

Safety, energy conservation, and environmental protection have become the three main development topics in the automobile industry of the twenty-first century as a result of the increasing levels of smog, the reduced availability of oil, and the safety concerns in road traffic accidents. With their advantages of zero emissions and low energy consumption, high levels of safety for new energy vehicles have become the current and future development directions for global car manufacturers. With the promulgation and implementation of the "Energy saving and new energy automobile industry development plan (2012-2020)" [5], all car manufacturers have been actively promoting the development of new energy vehicles, and a relatively mature vehicle integration development system has gradually been established [6, 7]. 330,000 new energy vehicles were sold in China in 2015, surpassing the USA to become the country with the highest use of these vehicles in the new energy area. China's new energy vehicle sales reached nearly 800,000 in 2017 , and this number is expected to reach approximately one million vehicles in 2018. In 2017, the government issued "The medium and long term development plan of the automobile industry," which indicated that the sales of new energy vehicles should reach two million in 2020, while also indicating that sales will reach seven million vehicles in 2025 . There is a huge market for 
new energy vehicles. At the same time, electric vehicles have become an effective solution to the problems of environmental protection and energy conservation.

Vehicle collision types usually include frontal impacts, side impacts, rolling and rear impacts. Statistics indicate that the probability of occurrence of vehicle rear impact is less than that of frontal and side impacts, but the probability of rear impact occurring in national highway traffic accidents is up to $44 \%$, which is far higher than the corresponding probabilities of other types of impact [8-10].

In vehicles using conventional fuel, the fuel tank is prone to rupture, which will cause fuel tank to leak or possibly even explode during or after a rear impact. Unlike traditionally fueled vehicles, electric vehicles not only have to consider the problem of crash safety, but also have associated highvoltage risks during use [11]. The operating voltage of an electric vehicle is much higher than that of a human. When an accident occurs, the high-voltage supply may fail to cut off in time, which would mean that the motor controller would not be discharged and the voltage would not be reduced to a safe level; this could easily lead to the risk of injury or even death from the high-voltage electrical equipment [12]. It is therefore very important to perform research on the highvoltage safety of electric vehicles during crashes [13, 14]. This study concerns the high-voltage safety optimization of an electric vehicle in a $50 \mathrm{~km} / \mathrm{h}$ rear impact. The battery pack, the motor controller, and the on-board charger may become

Table 1 Electrical safety standards for new energy vehicles

Statute

Insulation resistance

Passenger protection

Third party protection

Prevent short circuit

Over-current cutoff protection dangerous after the rear impact if the high-voltage of the electric motor controller is not cut off and the impact on the housing caused it to crack. This paper describes analysis and optimization of vehicle safety from several perspectives, including a high-voltage cutoff strategy, the integrity of the high-voltage parts after the crash, the layouts of the highvoltage and low-voltage cables, and the crashworthiness of the structure.

\section{Electric Vehicle High-Voltage Safety Standard}

In rear impact tests, the structural characteristics of new energy vehicles mean that the requirements of the GB200722006 "Fuel system safety requirements of passenger car rear impact" standard must be fulfilled and the vehicles must also comply with current electrical safety standards. At present, China mainly applies the GB/T19751-2005 "Hybrid electric vehicle safety requirements" and GB/T18384.1-2015 "Electric vehicle safety requirements" standards. While these are the recommended electrical safety standards in China, the potential involvement of danger to human life and property means that these vehicles should be designed in accordance with the highest mandatory requirements. In the USA, for example, the Federal Motor Vehicle Safety Standard (FMVSS) 305 for $80 \mathrm{~km} / \mathrm{h}$ rear impact is the compulsory

\begin{tabular}{|c|c|}
\hline Passenger protection & $\begin{array}{l}\text { If the storage device is arranged out the passenger } \\
\text { compartment, during crash test and after, battery } \\
\text { pack and its components (battery, battery module, } \\
\text { electrolyte) cannot be put into the passenger } \\
\text { compartment; if the storage device is arranged in } \\
\text { the passenger compartment, any movement should } \\
\text { ensure passenger safety; during crash test and } \\
\text { after, no electrolyte was put into the cabin, and the } \\
\text { energy storage device shall not explode or catch } \\
\text { fire; During the test, the electrolyte leakage } \leq 5 \mathrm{~L}\end{array}$ \\
\hline Third party protection & $\begin{array}{l}\text { During impact test, battery pack or its components } \\
\text { (power battery, battery module, electrolyte) shall } \\
\text { not be thrown out of the vehicle by impact }\end{array}$ \\
\hline Prevent short circuit & $\begin{array}{l}\text { During impact test, short circuit of power circuit } \\
\text { should be avoided }\end{array}$ \\
\hline Over-current cutoff protection & $\begin{array}{l}\text { Battery pack and power circuit systems shall be } \\
\text { protected by contactors and fuses. When the } \\
\text { current of the high-voltage circuit is too large, the } \\
\text { contactor and the fuse are automatically } \\
\text { disconnected from the battery pack }\end{array}$ \\
\hline
\end{tabular}

GB/T19751-2005, GB/T18384.1-2015, FMVSS305 $80 \mathrm{~km} / \mathrm{h}$ rear impact

After impact, the insulation resistance Ri divided by the nominal voltage of the power battery $\mathrm{Vb}, \mathrm{DC}$ circuit insulation resistance $\geq 100 \Omega / \mathrm{V}$, AC circuit insulation resistance $\geq 500 \Omega / \mathrm{V}$

If the storage device is arranged out the passenger compartment, during crash test and after, battery electrolyte) cannot be put into the passenger compartment; if the storage device is arranged in ensure passenger safety; during crash test and after, no electrolyte was put into the cabin, and the energy storage device shall not explode or catch

During impact test, battery pack or its components (power battery, battery module, electrolyte) shall not be thrown out of the vehicle by impact should be avoided

attery pack and power circuit systems shall be current of the high-voltage circuit is too large, the disconnected from the battery pack 
high-voltage safety-relevant standard. Details of the new energy automotive vehicle electrical safety standards are shown in Table 1.

\section{Analysis of High-Voltage Safety in Rear Impact Testing}

The rear part of a typical electric vehicle body is equipped with a large number of high-voltage (HV) components, including the battery pack, the HV distribution box, the wire harness, the motor controller, the motor, and the on-board charger. Figure 1 shows the HV parts contained in the rear space of vehicle A. Vehicle A is a midsize sport utility vehicle (SUV) with five seats.

\subsection{Test Conditions}

Vehicle B is a new style of vehicle A and has been developed to meet market demand. Because of the presence of the rear row of seats, the motor controller and the on-board charger have been placed between the rear row of seats and the rear plate; when a high-speed rear impact occurs, the motor controller and the on-board charger may easily be broken. More seriously, a rear impact may mean that the HV system cannot be cut off and could cause an HV short circuit, trigger an $\mathrm{HV}$ arc, and lead to a fire risk. To reduce the risk of rear impact by reducing the touch pressure safety risk while also shortening the research cycle, the research phase of vehicle B saw vehicle A being modified to produce vehicle $B$ through changes in the structure and packaging. Then, a rear impact test was conducted to evaluate the HV safety risks and design improvement countermeasures were implemented.

In this study, only the cutoff control signal, the body structure, the third row seat structure, and the wiring layout were optimized. Three rear impact tests were performed: two on vehicle $\mathrm{A}$ and one on vehicle $\mathrm{B}$. The test conditions are

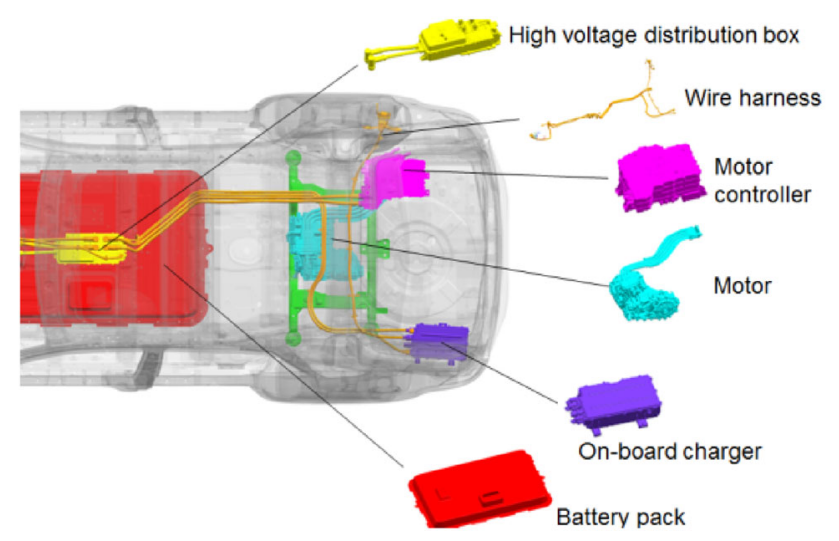

Fig. $1 \mathrm{HV}$ parts in the rear space of vehicle A
Table 2 Test conditions

\begin{tabular}{lll}
\hline Vehicle & $\begin{array}{l}\text { Distance between } \\
\text { motor controller and } \\
\text { rear plate }\end{array}$ & Load case \\
\hline A & $373 \mathrm{~mm}$ & $\begin{array}{l}50 \mathrm{~km} / \mathrm{h} 100 \% \text { rear } \\
\text { impact }\end{array}$ \\
& & GB 20072 \\
A & $373 \mathrm{~mm}$ & $80 \mathrm{~km} / \mathrm{h} 70 \%$ rear \\
& & impact FMVSS 305 \\
B & $53 \mathrm{~mm}$ & $50 \mathrm{~km} / \mathrm{h} 100 \%$ rear \\
& & impact \\
& & GB 20072 \\
\hline
\end{tabular}

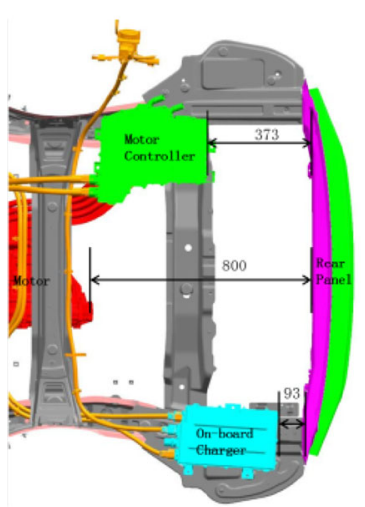

(a)

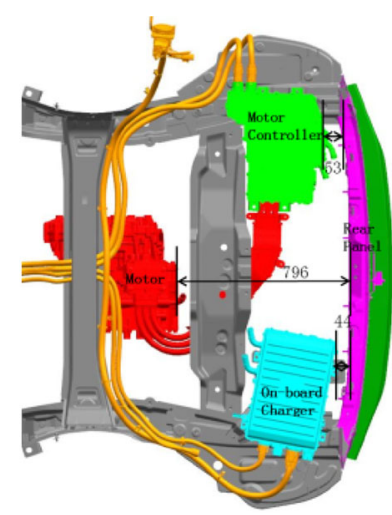

(b)
Fig. 2 Locations of motor controllers. a Vehicle A. b Vehicle B

described in detail in Table 2. The motor controller placement conditions are also shown in Fig. 2.

\subsection{Analysis of High-Voltage Cutoff and Door Unlock Control Signals}

\subsubsection{Theory of High-Voltage Cutoff Control Signal}

The most important factor in $\mathrm{HV}$ protection is the response time of the system to the crash or accident, i.e., shorter response times are more advantageous for the protection of the passengers and the HV system. The impact protection system must deal with the impact signals between the control modules. The theory of the high-voltage cutoff control signal in a rear impact scenario is illustrated schematically in Fig. 3. The function of the supplemental restraint system electronic control unit (SRS ECU) is to receive and process the collision signals.

When the rear impact occurs, the impact sensor transmits an impact alarm signal to the SRS ECU through a hard line. After the SRS ECU receives the impact signal, it determines whether the impact signal reaches the required threshold; if the answer is yes, then the SRS ECU sends an alarm sig- 


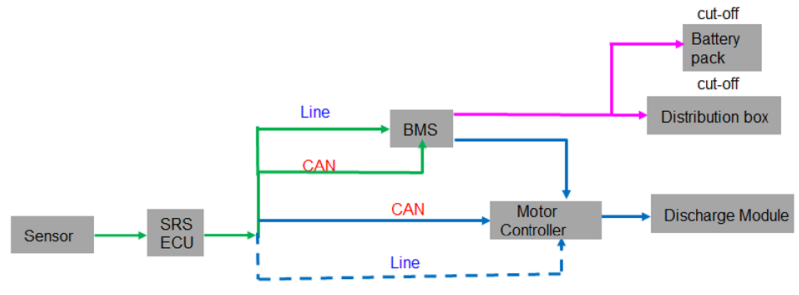

Fig. 3 Schematic illustrating HV cutoff and discharge theory

nal to the battery management system (BMS) and the motor controller.

The SRS ECU can send the alarm signal to the front motor controller in two forms, via a pulse width modulation (PWM) signal and using the controller area network (CAN); however, the alarm signal is sent to the motor controllers in CAN form only. When the front and rear motor controllers receive their cutoff signals from the BMS, they would cut off the highvoltage supplied by the battery pack. In addition, at the time when they received their impact signals from SRS ECU, they would also reduce their own operating voltages immediately.

\subsubsection{Theory of Door Unlock Control Signal}

When a rear impact occurs, to ensure that the passengers are able to escape from the car in time, the door unlock signal must also be sent in addition to the $\mathrm{HV}$ impact signal to allow the doors to unlock in time after the crash or accident. The theory of the rear door unlocking signal process is illustrated schematically in Fig. 4. The function of the SRS ECU is again to receive and process the collision signals.

When the rear impact occurs, the impact sensor transmits an impact alarm signal to the SRS ECU through a hard line. After the SRS ECU receives the impact signal, it determines whether the impact signal reaches the required threshold; if the answer is yes, then the SRS ECU will send an alarm signal to the body control module (BCM) through the line and through the CAN. The signal in the line is a PWM signal, while the signal in the CAN is a CAN message. The first signal to arrive between the PWM signal and the CAN message is dealt with by the BCM. After the BCM processes and analyzes the alarm signal, it would then send the unlock signal to the door motors.

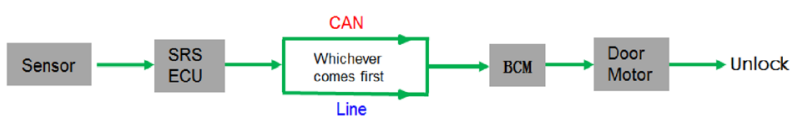

Fig. 4 Schematic of door unlock control signal process

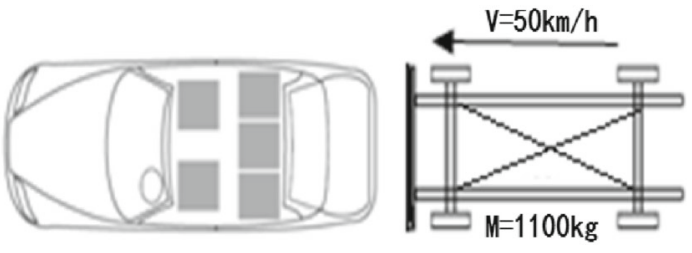

Fig. $550 \mathrm{~km} / \mathrm{h}$ rear impact test conditions

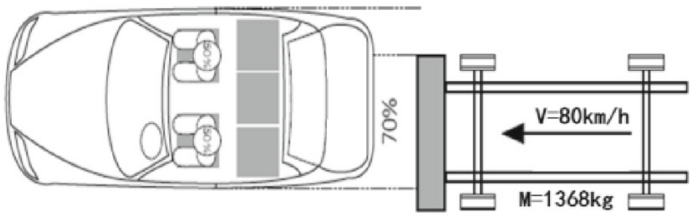

Fig. $680 \mathrm{~km} / \mathrm{h}$ rear impact test conditions

Table 3 Signal detection requirements

\begin{tabular}{ll}
\hline Parts & Signals \\
\hline BMS & General leakage signal \\
& Serious leakage signal \\
& Collision line signal \\
& $12 \mathrm{~V}$ power source \\
& Positive cutoff signal \\
& $12 \mathrm{~V}$ power source \\
Motor controller & High voltage \\
& Unlock door signal \\
\hline
\end{tabular}

\subsubsection{Analysis of the Cutoff Signal and the Unlock Signal}

To provide a more in-depth understanding of the cutoff behavior of the HV parts and the discharge performance of the vehicle under actual impact conditions, three rear impact tests were arranged. In these tests, vehicle A was subject to $50 \mathrm{~km} / \mathrm{h}$ and $80 \mathrm{~km} / \mathrm{h}$ rear impacts, while vehicle B was subject to a $50 \mathrm{~km} / \mathrm{h}$ rear impact. The $50 \mathrm{~km} / \mathrm{h}$ rear impact preparation and tests were carried out with reference to the GB 20072 standard, and the $80 \mathrm{~km} / \mathrm{h}$ rear impact preparation and test were carried out with reference to FMVSS 305 . The tests are illustrated schematically in Figs. 5 and 6.

The high-voltage and low-voltage control signals must be connected to the pins of each control module to enable analysis of the transmission path and time and the execution strategy for the control signal. After screening, the important signals that must be detected were finally identified as shown in Table 3.

After the impact tests, the complete resulting deformations of the three vehicles were as shown in Figs. 7, 8 and 9.

After analysis of the signals from the three tests, the deformations of each vehicle with respect to the signal time were obtained; the results corresponding to Figs. 7, 8 and 9 are shown in Figs. 10, 11 and 12, respectively. 
Fig. 7 Vehicle A: $50 \mathrm{~km} / \mathrm{h}$ rear impact

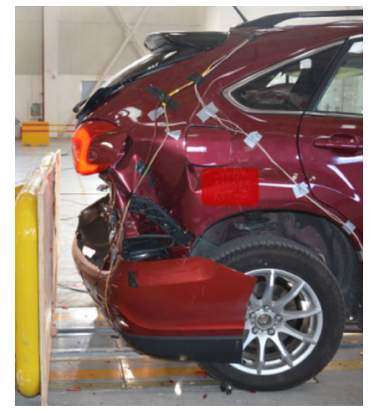

Fig. 8 Vehicle A: $80 \mathrm{~km} / \mathrm{h}$ rear impact

Fig. 9 Vehicle B: $50 \mathrm{~km} / \mathrm{h}$ rear impact

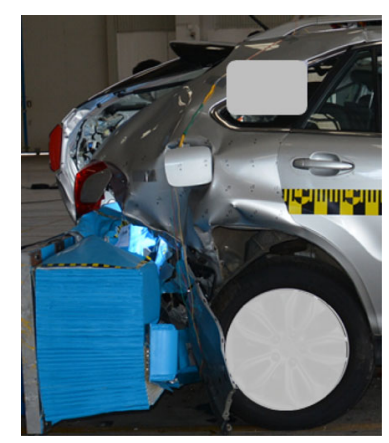

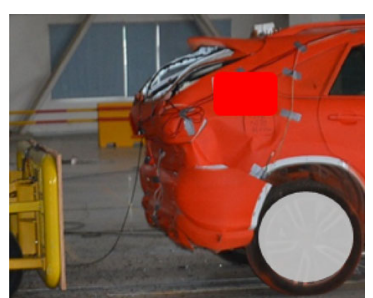

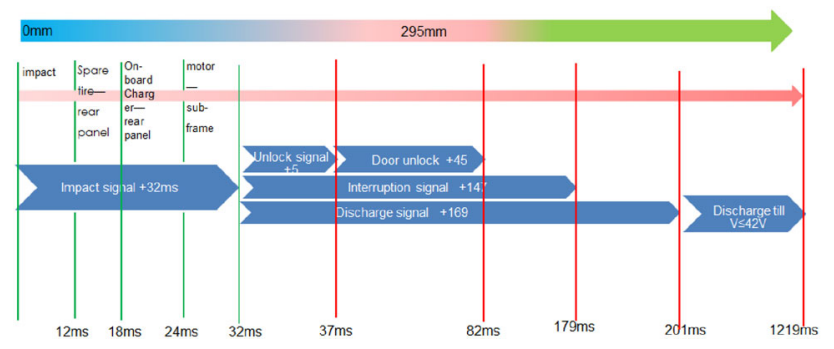

Fig. $1050 \mathrm{~km} / \mathrm{h}$ rear impact results for vehicle A

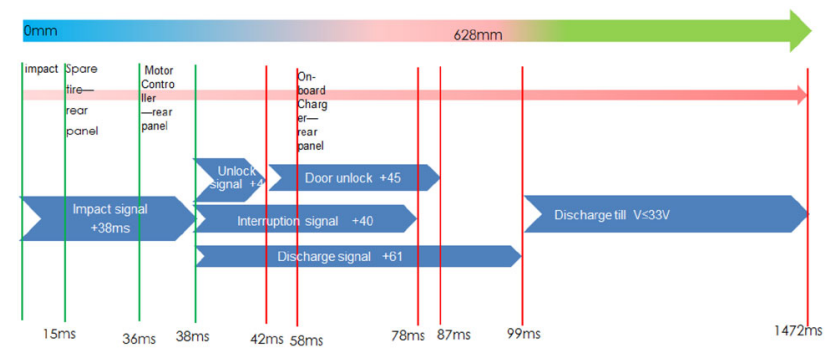

Fig. $1180 \mathrm{~km} / \mathrm{h}$ rear impact results for vehicle A

In all three tests, all the doors unlocked successfully. However, in the third test, the vehicle failed to cut off the high voltage and it was actively discharged. The results for door

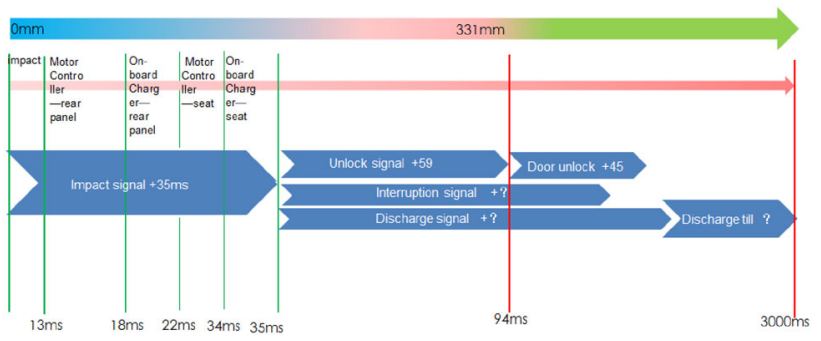

Fig. $1250 \mathrm{~km} / \mathrm{h}$ rear impact results for vehicle B

Table 4 Test results

\begin{tabular}{llll}
\hline Test & Door unlock & $\begin{array}{l}\text { High-voltage } \\
\text { cutoff }\end{array}$ & $\begin{array}{l}\text { Initiative } \\
\text { discharge }\end{array}$ \\
\hline A $50 \mathrm{~km} / \mathrm{h}$ & $\mathrm{Y}$ & $\mathrm{Y}$ & $\mathrm{Y}$ \\
A $80 \mathrm{~km} / \mathrm{h}$ & $\mathrm{Y}$ & $\mathrm{Y}$ & $\mathrm{Y}$ \\
B $50 \mathrm{~km} / \mathrm{h}$ & $\mathrm{Y}$ & $\mathrm{N}$ & $\mathrm{N}$ \\
\hline
\end{tabular}

unlocking, HV cutoff and discharge initiation performance are shown in Table 4.

When these results were combined with the control signal data and the results of analysis of the wire harnesses after impact, it was found that the causes of the failure in the third impact test were as follows:

1. The connector of the tire pressure monitor was pushed and broken by the rear panel, which caused the CAN high and CAN low connections to be shorted; this then caused paralysis of the vehicle CAN and the BMS; and the motor controller could not receive the CAN messages.

2. The motor controller was connected to the BMS only via the CAN and not via a hard line, so when the CAN was paralyzed, the motor controller could not receive the impact signal.

\subsection{Analysis of Acceleration and Deformation of High-Voltage Components}

Because this research is focused on HV safety, only the acceleration and deformation of the battery pack, the motor controller and the on-board charger are analyzed here. In terms of the HV cutoff performance, the first two tests were successful, but the third test was a failure. This section focuses on the acceleration and deformation of the HV components in the third test.

\subsubsection{Analysis of the Battery Pack}

Previous experience indicates that the acceleration of the battery pack is at its highest in the vicinity of the vehicle deformation area (or the battery deformation area). Therefore, the accelerations of the two ends of the battery pack were mainly monitored here. To prevent the measurement 


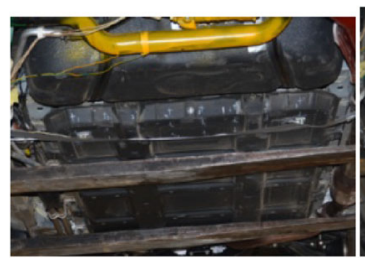

(a)

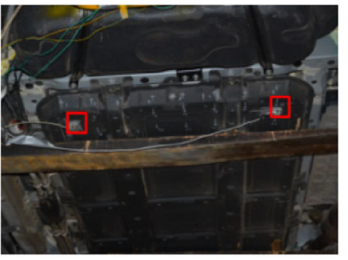

(b)
Fig. 13 States of the battery pack a pretest and $\mathbf{b}$ posttest

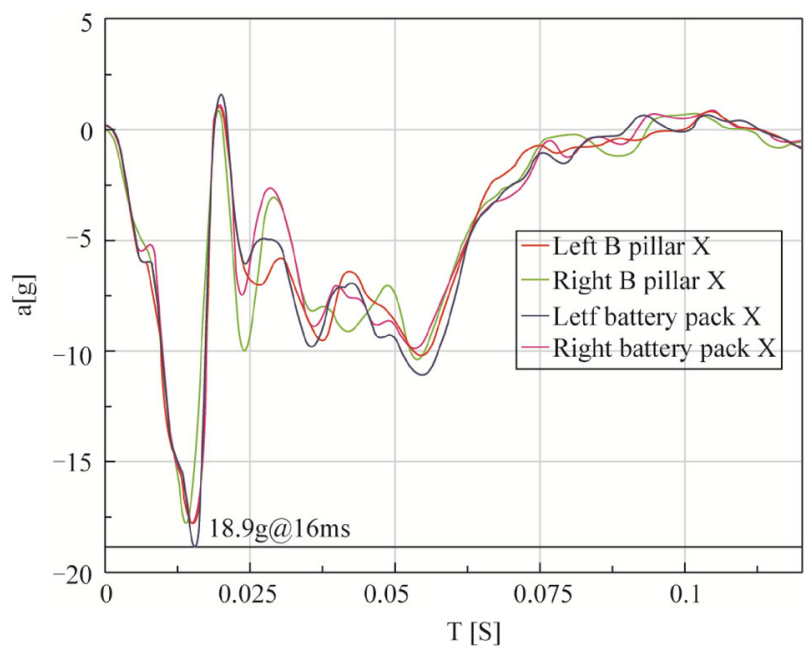

Fig. 14 Battery pack acceleration characteristics

values mentioned above from representing the impact acceleration of a single point, accelerometer sensors were placed on both sides of the battery pack during the test. However, the actual test results showed that the accelerations on the two sides were not very different. Because the battery pack was not squeezed, the accelerations of the ends of the battery pack were basically the same as the acceleration of the entire vehicle.

The maximum body (B pillar) acceleration was approximately $18 \mathrm{~g}$ and that of the battery pack was $18.9 \mathrm{~g}$, so the battery pack showed almost no extrusion deformation. The states of the battery pack before and after the test are shown in Fig. 13, in which the red boxes indicate the acceleration sensors. The acceleration curves of the battery pack are shown in Fig. 14.

\subsubsection{Analysis of the Motor Controller}

The motor controller was located between the rear panel and the seat, and the space between the motor controller and the rear panel was very small, as was the space between the motor controller and the seat. After the impact, the motor controller struck the hinged plate of seat and as a result, a hole was formed in the motor controller housing. If the housing shell fragments dropped onto the internal copper wires, this could

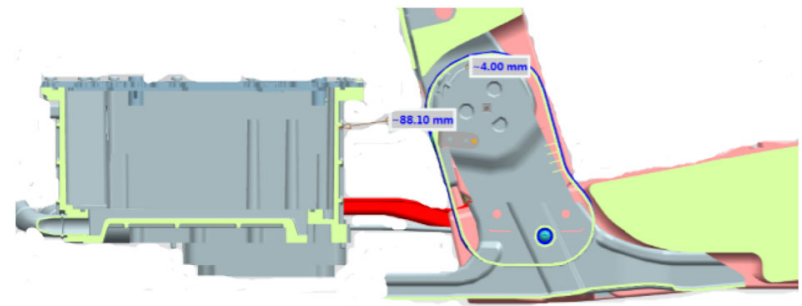

Fig. 15 Relative positions of motor controller and seat

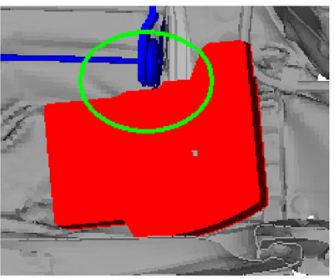

(a)

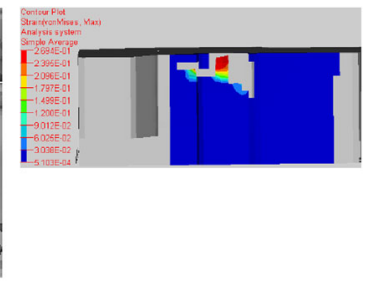

(b)
Fig. 16 Simulation of contact area between motor controller and seat

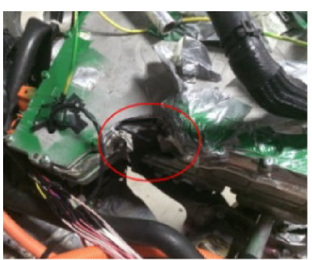

(a)

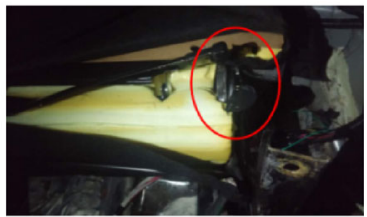

(b)
Fig. 17 Results of testing of the contact area between motor controller and seat. a Damaged area of motor controller. b Hinged plate of seat

cause an HV leakage and represent a fire risk. The relative positions of the motor controller and the seat are shown in Fig. 15. The simulation of the contact area between the motor controller and the hinged plate of the seat is illustrated in Fig. 16. The results of testing of the contact area between the motor controller and the hinged plate of the seat are shown in Fig. 17.

The maximum body (B pillar) acceleration was approximately $18 \mathrm{~g}$, while that of the motor controller was $198 \mathrm{~g}$, as shown in Fig. 18. The acceleration of the motor controller was approximately 10 times that of the body. This showed that the motor controller was pressed severely by the rear panel and the seat. At a time of approximately $13 \mathrm{~ms}$, the rear panel of the body started to make contact with the motor controller, and the motor controller then contacted the seat at approximately $22 \mathrm{~ms}$. The contact time curve is shown in Fig. 18 in the form of a voltage signal curve; initially, the voltage was $0 \mathrm{~V}$, but when the motor controller made contact with another part of the vehicle, the voltage rose.

Analysis of the damage area contact time curve and the acceleration curve indicated that, at the time of $22 \mathrm{~ms}$, the motor controller made contact with the hinged plate of the 

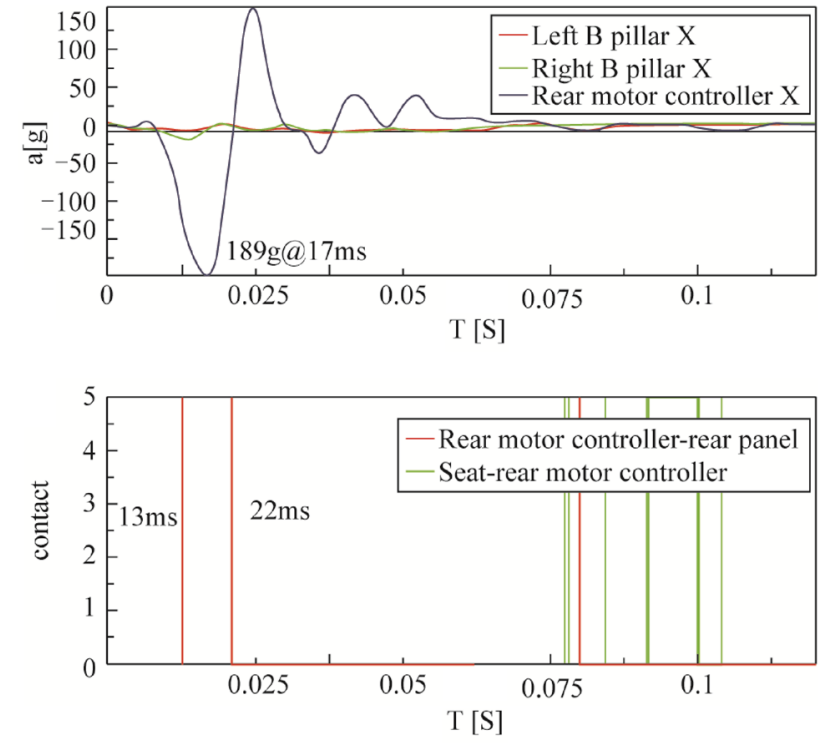

Fig. 18 Acceleration and contact time results of the motor controller
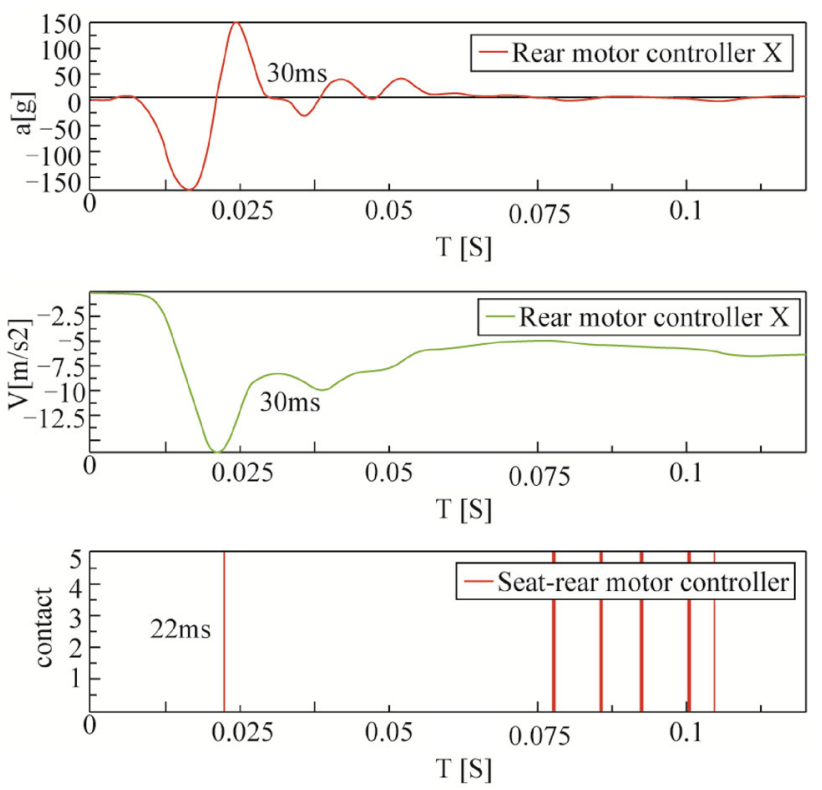

Fig. 19 Time characteristic showing when the motor controller was damaged

seat; at this moment, the velocity of the motor controller reached a maximum, and the motor controller started to be pressed strongly by both the rear panel and the seat. At the time of approximately $30 \mathrm{~ms}$, the acceleration changed to 0 because the housing was damaged by the formation of a hole, as indicated by Fig. 19, which shows a voltage signal curve where the voltage was initially $0 \mathrm{~V}$ and then rose when the motor controller made contact with another part of the vehicle.

\subsubsection{Analysis of On-Board Charger}

The on-board charger is packaged within the left side of the luggage compartment and is located between the rear panel and seat; the spaces between the on-board charger and the rear panel and between the on-board charger and the seat were both very small. The curve shown in Fig. 20 indicated that the on-board charger started to make contact with the seat at approximately $34 \mathrm{~ms}$. After the crash, the on-board charger was struck severely by the hinged plate of the seat, but was not damaged. The maximum on-board charger acceleration was $99 \mathrm{~g}$, which was much larger than the body acceleration of $18 \mathrm{~g}$, indicating that the on-board charger was struck violently during the impact. The contact time between the on-board charger and the seat and the on-board charger acceleration are shown in Fig. 20 in the form of a voltage signal curve, where the voltage was initially $0 \mathrm{~V}$, but the voltage rose when the motor controller made contact with another part of the vehicle. The state of the on-board charger after testing is shown in Fig. 21a, and the simulated state of the charger is shown in Fig. 21b.
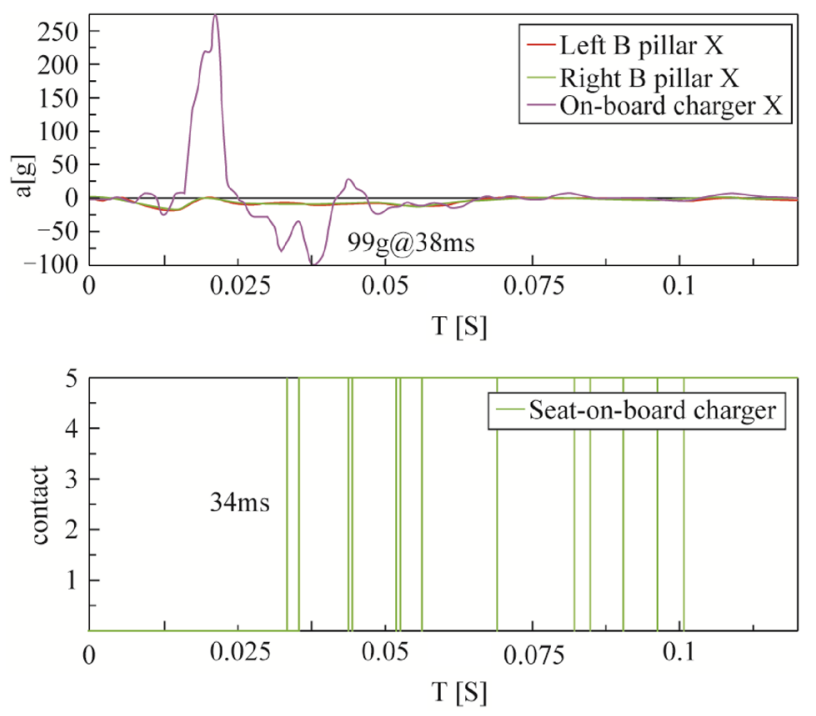

Fig. 20 On-board charger acceleration and contact time

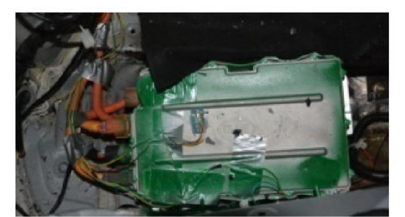

(a)

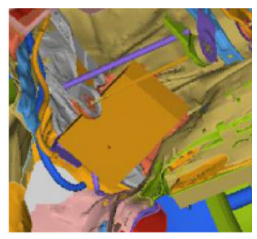

(b)
Fig. 21 On-board charger posttest and simulated states. a On-board charger after testing. b On-board charger simulation 


\subsection{Analysis of High-Voltage Leakage}

The HV electric leakage was monitored before and after the test. The resistance results are shown in Fig. 22, and the pretest and posttest insulation resistance values are listed in Table 5. Figure 22 shows the resistance values that were measured between the electric chassis and the HV storage/charger.

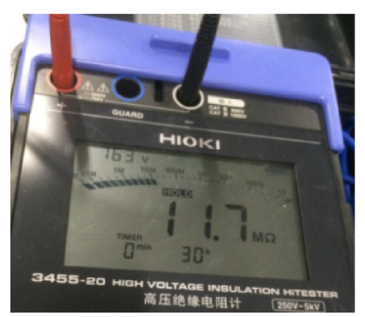

(a)

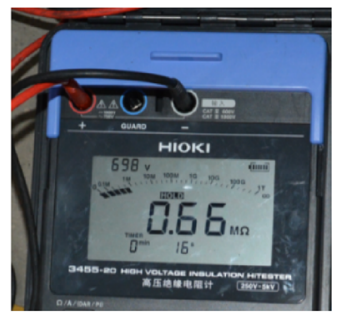

(b)
Fig. 22 Resistance measurement results. a Resistance measured pretest. b Resistance measured posttest

Table 5 Pretest and posttest insulation resistance

\begin{tabular}{lll}
\hline Item & Pretest & Posttest \\
\hline Voltage $(\mathrm{V})$ & 763 & 698 \\
Resistance $(\mathrm{M} \Omega)$ & 11.7 & 0.66 \\
Insulation resistance & 15,334 & 946 \\
$(\Omega / \mathrm{V})$ & & \\
\hline
\end{tabular}

Before the test was performed, the voltage was $763 \mathrm{~V}$, and the resistance was $11.7 \mathrm{M} \Omega$; after the test, the voltage changed to $698 \mathrm{~V}$, and the insulation resistance dropped to $0.66 \mathrm{M} \Omega$. The insulation resistance thus varies greatly before and after the test, which indicates that there may be a serious leakage.

\subsection{Test Results}

Based on analysis of the control signal and the acceleration and deformation results of the three rear impact tests, the results for the HV safety of vehicle B were finally obtained, as shown in Table 6.

\section{Optimization}

After analysis of the test data, the design improvement effort was focused on several aspects, including the HV cutoff strategy, the integrity of the HV parts after the crash, the layout of the high-voltage and lowvoltage cables, and the crashworthiness of the structure.

\subsection{Optimization of High-Voltage Cutoff Control Signal}

Using a combination of the data from the three tests that showed which module used the shortest time based on the
Table 6 HV safety test results for vehicle B

\begin{tabular}{|c|c|c|c|}
\hline Item & Requirement & Test result & Meet requirement or not \\
\hline Battery pack & $\begin{array}{l}\text { No extrusion, no } \\
\text { shedding, no leakage, } \\
\text { no fire }\end{array}$ & $\begin{array}{l}\text { No extrusion, no } \\
\text { shedding, no leakage, } \\
\text { no fire }\end{array}$ & Yes \\
\hline Motor controller & $\begin{array}{l}\text { Housing no deformed, } \\
\text { high-voltage wire and } \\
\text { low-voltage wire no } \\
\text { fault and short circuit }\end{array}$ & Housing serious damage & No \\
\hline On-board charger & $\begin{array}{l}\text { Housing no deformed, } \\
\text { high-voltage wire and } \\
\text { low-voltage wire no } \\
\text { fault and short circuit }\end{array}$ & Housing no deformation & Yes \\
\hline Low-voltage signal wire & No fault and short circuit & $\begin{array}{l}\text { Tire pressure monitoring } \\
\text { module connector } \\
\text { broken, CAN high and } \\
\text { CAN low short circuit }\end{array}$ & No \\
\hline Door unlock & Normal unlock & Unlock & Yes \\
\hline High-voltage cutoff & Normal cutoff & Not cutoff & No \\
\hline Leakage situation & $\begin{array}{l}\text { Insulation resistance } \\
\geq 500 \Omega / \mathrm{V}\end{array}$ & $946 \Omega / \mathrm{V}$, serious leakage & No \\
\hline
\end{tabular}


HV cutoff control signals, ideal conditions were obtained that indicated that the best time for the HV cutoff level in the ideal state was $93 \mathrm{~ms}$. However, by this time, the invasion of the car body had already reached the maximum distance of $331 \mathrm{~mm}$, and the motor controller had already broken at $30 \mathrm{~ms}$. Therefore, in the ideal state, the HV cutoff control signal could not meet the safety requirements and it is thus necessary to optimize the HV cutoff control signal.

After the preliminary analysis and theoretical calculations were combined with the optimal design for the body structure, it was determined that if the main contactor broke at $50 \mathrm{~ms}$ or so, it may then meet the $\mathrm{HV}$ safety requirements. To realize the target value of the $50 \mathrm{~ms}$ cutoff, the signal processing logic requirements for each of the modules were as shown below:

1. Shorten the impact signal time;

2. Optimize the CAN message processing time;

3. Shorten the impact signal processing time;

4. Optimize the contactor breaking time;

5. Add a line for control signal transmission.

The ideal state of the HV cutoff control signal transmission time and the optimized signal transmission time is shown in Fig. 23.

\subsection{Optimization of Structural Layout}

\subsubsection{Optimization of Rear Longitudinal Beam}

When a general plastic material beam structure is extruded, the yield stress is $\sigma_{\mathrm{s}}$. The allowable stress of the material is:

$[\sigma]=\frac{\sigma_{\mathrm{s}}}{n_{\mathrm{s}}}$

where $n_{\mathrm{S}}$ is the safety factor of the material, which generally satisfies $n_{\mathrm{s}}>1$. When the beam structure is extruded, the maximum force that acts on the section is $F_{N \max }$, and the section is represented by $A$. The maximum working stress of the beam structure must be less than that of the material, such that:

$\sigma_{\max }=F_{N \max } / A \leq \sigma_{\mathrm{s}} / n_{\mathrm{s}}<\sigma_{\mathrm{s}}$

when the $\sigma_{\mathrm{S}}$ of the beam structure's material is increased and $A$ remains unchanged, then $\sigma_{\max }$ and $F_{N \max }$ will also both increase.

During the entire crushing process, the total energy of the rigid barrier is $E_{\mathrm{k}}$, while the maximum crushing force of the beam section is $F_{N \max }$ and the beam deformation is $S$. Suppose that all the kinetic $E_{\mathrm{k}}$ of the rigid barrier during the collision is transformed into the internal energy of the beam crushing deformation. This can be represented by the following formula:

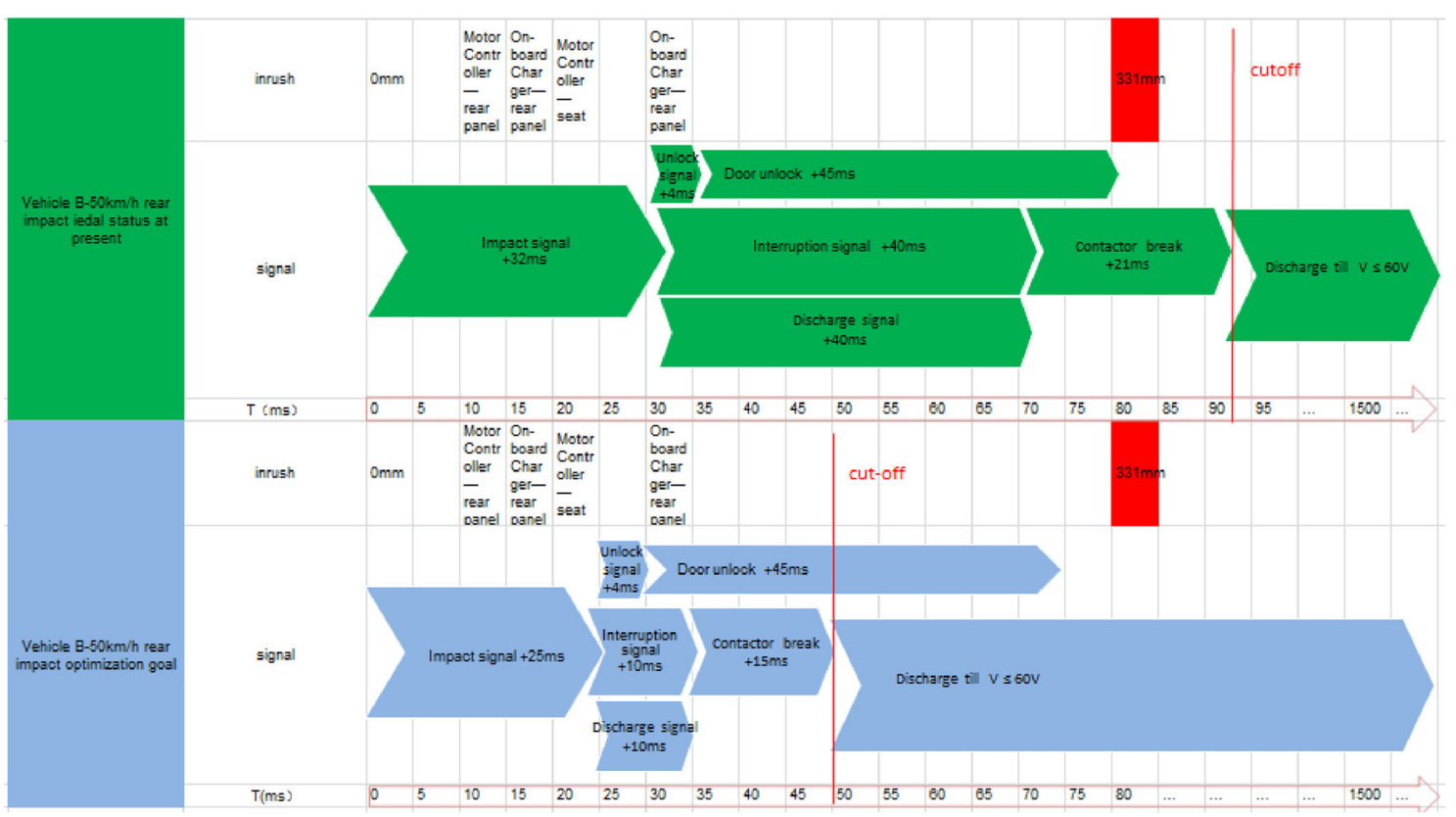

Fig. 23 Control signal transmission times 
Table 7 Material parameters of rectangular beams

\begin{tabular}{lcccll}
\hline Materials & $E(\mathrm{GPa})$ & $\rho\left(\mathrm{kg} / \mathrm{mm}^{3}\right)$ & $\mu$ & $\sigma_{\mathrm{s}}(\mathrm{MPa})$ & $\sigma_{\mathrm{b}}(\mathrm{MPa})$ \\
\hline Al & 71 & $2.81 \times 10^{-6}$ & 0.3 & 455 & - \\
B250 & 210 & $7.89 \times 10^{-6}$ & & 250 & 635 \\
B250P1 & & & & 288 & 700 \\
& & & 308 & 555 \\
& & & & 308 & 760 \\
\hline
\end{tabular}

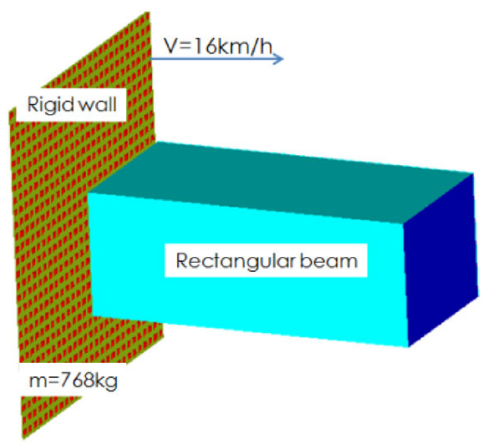

Fig. 24 Simple CAE crash model

By combining formulas (2) and (3), we can obtain the following:

$E_{\mathrm{k}}=\sigma_{\max } \cdot A \cdot S$

The following is then known from formula (4):

$S=E_{\mathrm{k}} / \sigma_{\max } \cdot A$

$E_{\mathrm{k}}$ has a constant value, as does $A$. Therefore, when $\sigma_{\max }$ is raised, $S$ will be reduced accordingly.

To verify the accuracy of the above theoretical deduction, a simplified numerical simulation was performed $[15,16]$. A rigid barrier with a mass of $768 \mathrm{~kg}$ crushed a rectangular beam at a speed of $16 \mathrm{~km} / \mathrm{h}$. The sectional parameters of the rectangular section beams were $60 \times 80 \mathrm{~mm}$, the material thickness was $1.65 \mathrm{~mm}$, and the length was $160 \mathrm{~mm}$. The different material parameters used for the rectangular section beams are listed in Table 7 . The simple computer-aided engineering (CAE) crash model is shown in Fig. 24.

The relationships between the energy absorption and the deformation of the rectangular beams made from the different materials are shown in Fig. 25. The stroke utilization ratio $\left(S_{\text {te }}\right)$ values of the rectangular beams composed of the different materials are listed in Table 8 .

Figure 25 indicates that the kinetic energy of the rigid barrier was basically transformed into the internal energy of the rectangular section beam. The $S_{\text {te }}$ results listed in Table 8 reflect the amount of cross section deformation that occurs in the different materials when they absorb the same energy. The

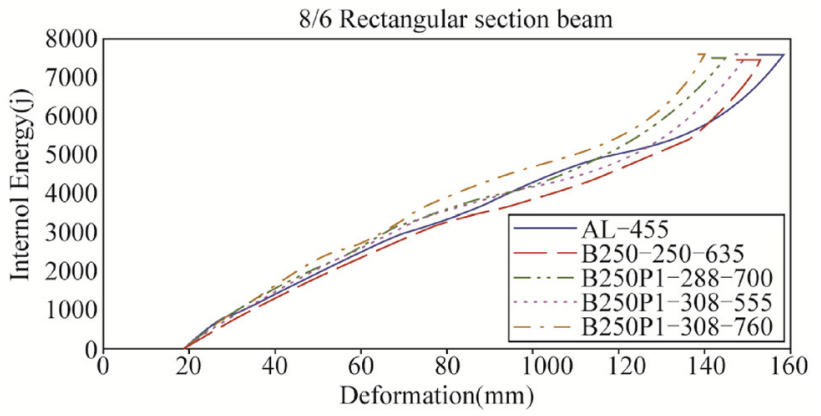

Fig. 25 Internal energy and deformation of the rectangular beams

Table $8 S_{\text {te }}$ values of beam materials

\begin{tabular}{llll}
\hline Materials & $L(\mathrm{~mm})$ & $S(\mathrm{~mm})$ & $S_{\text {te }}(S / L)$ \\
\hline AL-455 & 160 & 138.403 & 0.865 \\
B250-250-635 & & 132.974 & 0.831 \\
B250P1-288- & & 124.671 & 0.779 \\
$\quad 700$ & & \\
B250P1-308- & & 129.461 & 0.809 \\
$\quad$ 555 & & \\
B250P1-308- & & 120.2 & 0.751 \\
760 & & \\
\hline
\end{tabular}

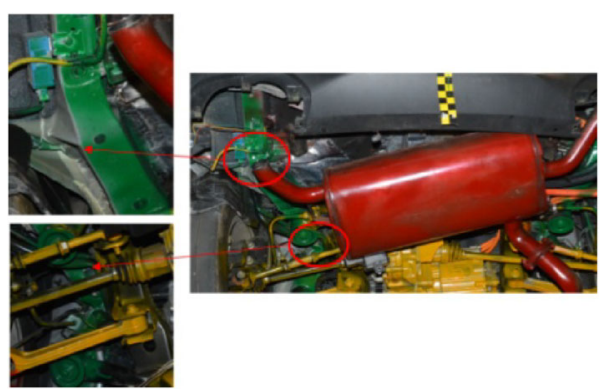

Fig. 26 Posttest deformation of rear longitudinal beam

overall trend for the stroke utilization ratio of these materials with the same cross section is as follows: higher material strength corresponds to a lower stroke utilization ratio [17]. These results proved that, because both $E_{\mathrm{k}}$ and $A$ remain unchanged, when $\sigma_{\max }$ is increased, then $S$ will decrease accordingly.

The deformation results from vehicle testing and simulations were compared and analyzed, and an optimization scheme was proposed. The test and simulation results for the deformation of the rear longitudinal beam are shown in Figs. 26 and 27, respectively. Comparison of the test and simulation results showed that two regions in the rear longitudinal beam were relatively weak, and the deformation in these regions was obvious. The structures of these regions must therefore be optimized. The rear longitudinal beam was thus optimized based on the theoretical analysis and a simplification of the simulation results. 


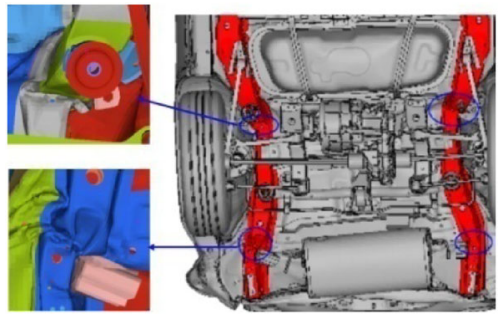

Fig. 27 Deformation of rear longitudinal beam determined by simulation

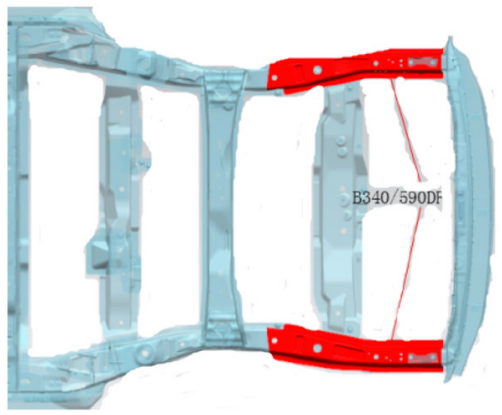

Fig. 28 Structural optimization of rear longitudinal beam

Table 9 Whole vehicle deformation for test and simulation

\begin{tabular}{lll}
\hline State & $\begin{array}{l}\text { Whole vehicle } \\
\text { deformation (rear } \\
\text { beam) }[\mathrm{mm}]\end{array}$ & \\
\cline { 2 - 3 } & Test & Simulation \\
\hline Before optimization & 359 & 339 \\
After optimization & 331 & 310 \\
\hline
\end{tabular}

The optimization of the rear longitudinal beam involved changing the material from B250 to B340, which could effectively improve the energy absorption ability of the rear longitudinal beam; the optimization is illustrated in Fig. 28.

The test and simulation analysis results for vehicle deformation before and after the optimization of the longitudinal beam are listed in Table 9. The results show that after the material was changed from B250 to B340, the deformation of the vehicle body decreased significantly.

\subsubsection{Optimization of Seat}

Because the motor controller was pushed by both the rear panel and the hinged plate of the seat, and the resulting stress was beyond the allowable stresses of both the structure and the material, the housing of the motor controller was damaged and a hole was formed. Here, the design of the hinged plate of the seat was improved by moving the limiting block forward, while the hinged plate outward ( $Y$ direction) flang-

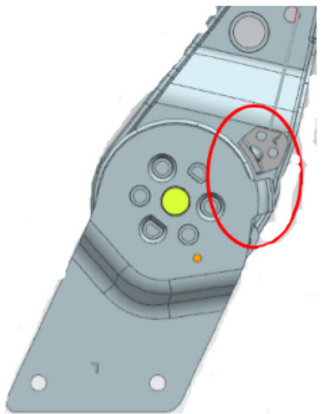

(a)

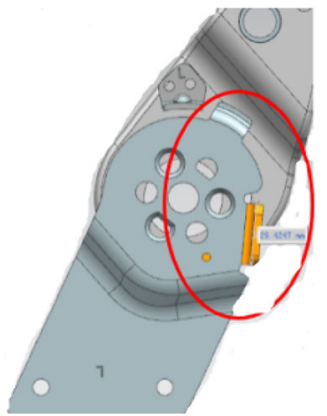

(b)
Fig. 29 Optimization of hinged plate structure. a Hinged plate before optimization. b Hinged plate after optimization

ing was increased to $15 \mathrm{~mm}$, with flanging in the $Z$ direction to increase the length to $30 \mathrm{~mm}$. The hinged plate structures before and after optimization are shown in Fig. 29.

\subsubsection{Motor Controller Protection}

It is assumed that the impact force of the motor controller back toward the seat is $F$, the impact force of the hinged plate of the seat toward the motor controller is $F_{1}$, the contact area between the electrically controlled shell and the seat hinge plate is $A$, the stress of the motor controller is $\sigma$, and the allowable stress of the motor controller is $[\sigma]$.

It is known from Newton's third law that

$F=F_{1}$

The relationship between the force and the stress is:

$F_{1}=\sigma \cdot A$

Therefore, from formulas (6) and (7), we know that:

$F=\sigma \cdot A$

It is assumed that when the impact force $F$ of the motor controller toward the seat is constant, then $\sigma$ will decrease correspondingly with increasing $A$. When formula (9) is satisfied:

$\sigma=F / A \leq[\sigma]$

then the motor controller will not be broken.

To increase the contact area and reduce the contact stress, a 4-mm steel plate was added in front of the motor controller. The steel plate was fixed on the front face of the motor controller using a bolt. The steel plate position is illustrated in Fig. 30. Simulations and tests were performed to compare and analyze the effects of addition of the steel plate. The results of the simulation analysis are shown in Fig. 31, and 


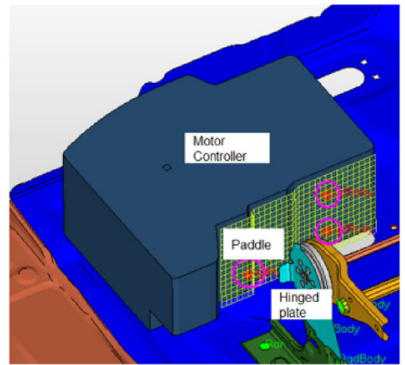

Fig. 30 Steel plate position
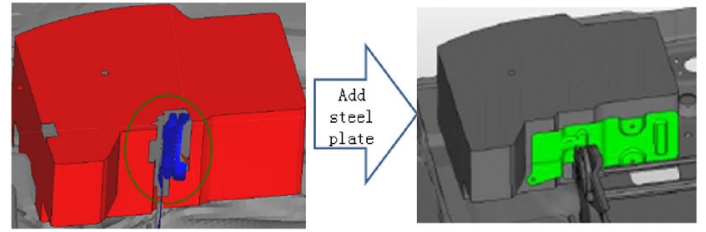

Fig. 31 Simulation comparison of steel plate addition

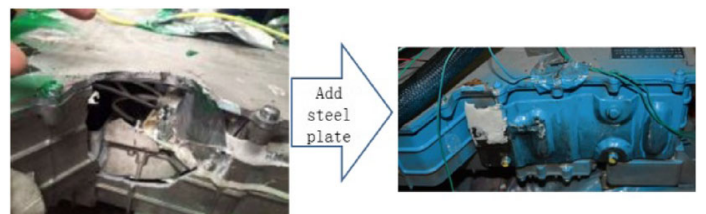

Fig. 32 Test comparison of steel plate addition

the test results are shown in Fig. 32. These simulation and test results show that the steel plate plays an important role in protecting the motor controller.

\subsubsection{Optimization of the Floor Wiring Harness}

During the impact, the low-voltage connector of the motor controller was seriously pressed by the rear panel, and when the connector was fractured before the control signal was received, the discharge function would fail. Therefore, the positioning of the low-voltage connector should be changed. The analysis indicated that the low-voltage connector should be moved to a place where there is a larger gap between the

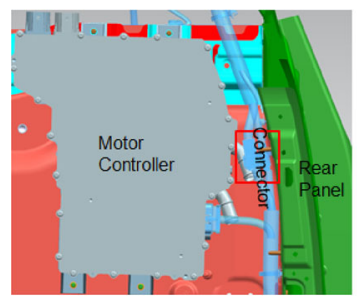

(a)

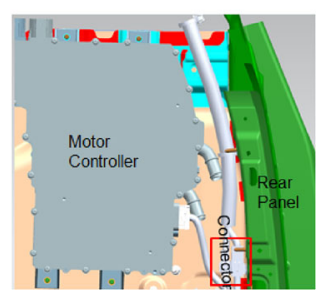

(b)
Fig. 33 Positions of the low-voltage connector. a Old position of lowvoltage connector. b New position of low-voltage connector

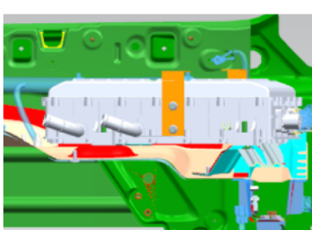

(a)

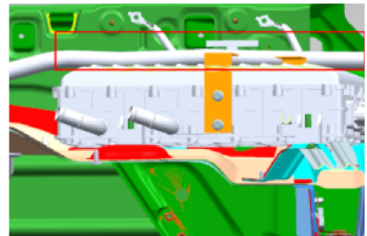

(b)
Fig. 34 Positioning of low-voltage wire. a Old position of low-voltage wire. $\mathbf{b}$ New position of low-voltage wire

rear panel and the motor controller. The old and new positions of the low-voltage connector are illustrated in Fig. 33.

Because the low-voltage wire was arranged along the rear panel and was fully coincident with the on-board charger in the $Z$ direction, if a serious rear impact occurred, then the low-voltage wire risked being compressed or even ruptured by the back panel and the on-board charger. Therefore, it was necessary to rearrange the low-voltage wire positioning. Analysis showed that moving the low-voltage wire up in the $Z$ direction by $25 \mathrm{~mm}$ can effectively avoid the failure risk. The old and new positions of the low-voltage wire are shown in Fig. 34.

\subsection{Analysis of Simulation Results}

Because the simulations could not simulate the situation in which the wire harness was squeezed and sheared, only the deformation of the structure has been simulated and analyzed here. A CAE simulation analysis was used to produce two structural optimization combinations:

1. Both rear longitudinal beam optimization and seat optimization.

2. Rear longitudinal beam optimization, seat optimization and addition of the steel plate.

The simulation results for the forces and stresses of the motor controller and the seat for the original case, case (1) and case (2) are listed in Table 10.

As shown in Table 5, in case (2), the maximum stress of the motor controller was reduced by $87 \mathrm{MPa}$ when compared with the original case. Therefore, case (2) was used as the final optimization strategy.

Table 10 Force and stress between motor controller and seat

\begin{tabular}{lrll}
\hline Case & Max force (N) & $\begin{array}{l}\text { Max stress } \\
(\mathrm{MPa})\end{array}$ & $\begin{array}{l}\text { Reduction of } \\
\text { the original } \\
\text { scheme (MPa) }\end{array}$ \\
\hline Original & 10,000 & 213 & - \\
Case (1) & 7500 & 169 & 44 \\
Case (2) & 12,000 & 126 & 87 \\
\hline
\end{tabular}


Table 11 Whole vehicle rear impact HV safety strategy

\begin{tabular}{|c|c|c|c|c|}
\hline $\begin{array}{l}\text { Optimization } \\
\text { direction }\end{array}$ & Model/signal & $\begin{array}{l}\text { Prioritization } \\
\text { scheme }\end{array}$ & $\begin{array}{l}\text { Results of CAE } \\
\text { and theory }\end{array}$ & $\begin{array}{l}\text { Results of whole } \\
\text { vehicle rear crash } \\
\text { test }\end{array}$ \\
\hline \multirow[t]{4}{*}{ Control signal } & Impact signal & $\leq 25 \mathrm{~ms}$ & Theory feasible & $24 \mathrm{~ms}$ \\
\hline & Interruption signal & $\leq 10 \mathrm{~ms}$ & Theory feasible & $9 \mathrm{~ms}$ \\
\hline & Interruption signal & $\begin{array}{l}\text { Add a line signal, } \\
\text { signal processing } \\
\text { time } \leq 10 \mathrm{~ms}\end{array}$ & Theory feasible & \\
\hline & Contactor & $\begin{array}{l}\text { Cutoff time } \\
\leq 15 \mathrm{~ms}\end{array}$ & Theory feasible & $15 \mathrm{~ms}$ \\
\hline \multirow[t]{3}{*}{ Layout } & Floor wire & $\begin{array}{l}\text { Connector avoid } \\
\text { the near location } \\
\text { of motor } \\
\text { controller and } \\
\text { rear plate; } \\
\text { low-voltage wire } \\
\text { up } 25 \mathrm{~mm} \text { in } Z \\
\text { direction to avoid } \\
\text { on-board charger }\end{array}$ & $\begin{array}{l}\text { Model analysis } \\
\text { feasible }\end{array}$ & OK \\
\hline & Motor controller & $\begin{array}{l}\text { As much as } \\
\text { possible increase } \\
\text { the space and } \\
\text { contact extrusion } \\
\text { area between } \\
\text { motor controller } \\
\text { and rear or front } \\
\text { rigid parts }\end{array}$ & $\begin{array}{l}\text { CAE simulation } \\
\text { feasible }\end{array}$ & OK \\
\hline & On-board charger & $\begin{array}{l}\text { As much as } \\
\text { possible increase } \\
\text { the space and } \\
\text { contact extrusion } \\
\text { area between } \\
\text { on-board charger } \\
\text { and rear or front } \\
\text { rigid parts }\end{array}$ & $\begin{array}{l}\text { CAE simulation } \\
\text { feasible }\end{array}$ & OK \\
\hline \multirow[t]{3}{*}{ Structure } & $\begin{array}{l}\text { Rear longitudinal } \\
\text { beam }\end{array}$ & $\begin{array}{l}\text { Change the } \\
\text { material from } \\
\text { B250 to B340 }\end{array}$ & $\begin{array}{l}\text { CAE simulation } \\
\text { feasible }\end{array}$ & OK \\
\hline & Seat & $\begin{array}{l}\text { Hinged plate } \\
\text { outward ( } Y \\
\text { direction) } \\
\text { flanging to } \\
15 \mathrm{~mm} \text {, flanging } \\
\text { in the direction of } \\
\mathrm{Z} \text { to increase the } \\
\text { length of } 30 \mathrm{~mm}\end{array}$ & $\begin{array}{l}\text { CAE simulation } \\
\text { feasible }\end{array}$ & OK \\
\hline & Steel plate & $\begin{array}{l}\text { Add a 4-mm steel } \\
\text { plate in front of } \\
\text { motor controller }\end{array}$ & $\begin{array}{l}\text { CAE simulation } \\
\text { feasible }\end{array}$ & OK \\
\hline
\end{tabular}

\subsection{Whole Vehicle Rear Impact High-Voltage Safety Strategy}

The basic idea of the HV safety strategy for whole vehicle includes the following:

1. Optimize the control signal processing program for the HV cutoff. Based on a premise of signal sensitivity and accuracy, the signal processing and response times of each module were shortened as far as possible to complete the door unlock and HV cutoff steps in the shortest possible time, thus ensuring the completion of transmission and confirming all control signals before the motor controller is broken.

2. Strengthen the rear longitudinal beam structure to reduce the collapse rate while absorbing more impact energy. 
Table 12 Conclusions of test for whole vehicle HV safety

\begin{tabular}{|c|c|c|c|}
\hline Assessment items & Requirements & $\begin{array}{l}\text { Results of whole vehicle } \\
\text { rear crash test }\end{array}$ & Conclusions \\
\hline \multirow[t]{2}{*}{ Insulation resistance } & $\begin{array}{l}\text { REESS to vehicle body: } \\
\geq 100 \Omega / \text { VDC }\end{array}$ & 3556 & $\sqrt{ }$ \\
\hline & $\begin{array}{l}\text { High-voltage machine to } \\
\text { vehicle body: } \\
\geq 500 \Omega / \text { VAC or } \\
100 \Omega / \text { VDC }\end{array}$ & 2953 & $\sqrt{ }$ \\
\hline Electrolyte leakage & $\begin{array}{l}\text { There should be no } \\
\text { electrolyte overflow } \\
\text { from REESS to the } \\
\text { occupant cabin, and no } \\
\text { more than 5.0L of } \\
\text { electrolyte should } \\
\text { overflow from REESS }\end{array}$ & No leakage & $\sqrt{ }$ \\
\hline $\begin{array}{l}\text { REESS mobility } \\
\text { requirement }\end{array}$ & $\begin{array}{l}\text { The REESS in the } \\
\text { occupant cabin should } \\
\text { be kept in the } \\
\text { installation position. } \\
\text { The REESS parts } \\
\text { should be kept in its } \\
\text { enclosure and should } \\
\text { not enter the occupant } \\
\text { cabin }\end{array}$ & Remain intact & $\sqrt{ }$ \\
\hline $\begin{array}{l}\text { REESS fire and } \\
\text { explosion requirement }\end{array}$ & $\begin{array}{l}\text { At the end of the test } \\
30 \text { min, REESS does } \\
\text { not fire and explode }\end{array}$ & No fire & $\sqrt{ }$ \\
\hline
\end{tabular}

Increasing the contact area between the motor controller and the third row of seats avoids the phenomenon of stress concentration, thus reducing the contact stress.

3. Optimize the paths of the floor wiring, thus reducing the risk of wires being pressed and sheared.

To verify the above strategy, theoretical deductions, CAE simulations and real vehicle tests were carried out. The final determination of the electric vehicle HV safety strategy requirements during rear impact is listed in Table 11. The results of an HV safety assessment of a vehicle after a $50 \mathrm{~km} / \mathrm{h}$ collision test are given in Table 12 .

\section{Conclusions}

To improve the HV safety performance of electric vehicles during rear impact, the following actions were determined:

1. Optimize the HV power-off control signal program by shortening the signal processing and response times of each module, thus ensuring HV cutoff before the motor controller can be broken.

2. Strengthen the rear longitudinal beam structure by allowing outward ( $Y$ direction) flanging of the hinged plate of the seat to $15 \mathrm{~mm}$, flanging in the $Z$ direction to increase the length to $30 \mathrm{~mm}$, and adding a 4-mm-thick steel plate in front of the motor controller.

3. Rearrange the low-voltage connector layout to prevent it from being located near the motor controller or the rear plate, while also optimizing the path of the floor wires and moving the low-voltage wire up by $25 \mathrm{~mm}$ in the $Z$ direction to avoid the on-board charger. The space and the contact extrusion area between the motor controller and the rigid rear or front parts and the space and the contact extrusion area between the on-board charger and the rigid rear or front parts should also be increased as far as possible.

The theoretical analysis and simulation results showed that the proposed optimization scheme can improve the safety of the motor controller, and it is not difficult to implement the projected changes. At a later stage, the proposed optimization scheme will be verified via real vehicle testing. This research has reference value for the development of the signal control strategy, structure, and layout to ensure the HV safety of electric vehicles.

Acknowledgements The authors would like to thank BYD planning institute, BYD new energy vehicle crash laboratory, BYD CAE department, BYD electric vehicle technology development center, for their technology support. Thanks are also due to BYD chairman Wang Chuanfu, or his interest, support, and valuable advice. 
Open Access This article is distributed under the terms of the Creative Commons Attribution 4.0 International License (http://creativecomm ons.org/licenses/by/4.0/), which permits unrestricted use, distribution, and reproduction in any medium, provided you give appropriate credit to the original author(s) and the source, provide a link to the Creative Commons license, and indicate if changes were made.

\section{References}

1. Ma, M.T., Yi, H.L., Lu, H.Z., Wan, X.M.: On the automobile lightweight. Eng. Sci. 02, 71-77 (2012)

2. Ma, M.T., Lu, H.Z., Li, Z.G.: Automotive lightweight and advanced forming technologies. Mater. Mach. Eng. 32(2), 5-9 (2008) (in Chinese)

3. Azuma, Y. (ed.): Weight reduction of automobile by high strength steel. In: Niobium Microalloyed Sheet Steels for Automotive Applications, pp. 74-80. The Minerals, Metals Materials Society, Brasilia (2006)

4. SAE China: Blue Book of Automotive Industry, pp. 22-24. Social Sciences Academic Press, Beijing (2010)

5. State Council of the PRC: Energy saving and new energy automobile industry development plan (2012-2020). http://www.china.co m.cn/. Accessed 09 July 2012

6. Wang, J., Chen, J.H.: Research on the rear-end impact test technology of new energy vehicle. New Technol. New Process 04, 27-30 (2013)

7. Fu, X.F., Zhai, Y.X., Xiao, S., Wang, Q.Q.: Power battery high voltage safety management for extended ranged electric vehicle. Automob. Technol. 10, 44-49 (2014)
8. Wu, H.J.: Optimization of structure safety for a SUV car in highspeed rear-end collision. Yanshan Uinversity, Qinhuangdao (2014) (in Chinese)

9. Shi, Y., Zhu, P., Zhang, Y., et al.: A study on the lightweighting of car body structure based on stiffness and crashworthiness requirements. Automot. Eng. 32(9), 757-762 (2010) (in Chinese)

10. Viano, D.C., Parenteau, C.S.: Front-to-rear crashes involving two vehicles with severe driver injury. Traffic Injury Prevent. 1(3), 55-60 (2012)

11. Su, Z.G., Long, J.Q., Zhou, S.J.: Safety simulation of rear-end impact and experimental study for extended range electric vehicle. China Mech. Eng. 24(07), 964-970 (2013)

12. Ye, Z.B., Fu, X.F., Zhou, S.J.: The safety simulation of rear-end impact and experimental study of HEV. J. South China Univ. Technol. (Natural Science Edition) 39(11), 138-143 (2011)

13. Jie, G.L., Zhu, X.C., Cao, Y.X., et al.: Risks and simulation analysis of electric safety in electric vehicle crash. Automob. Technol. 3, 42-46 (2015) (in Chinese)

14. Kukreja, J., Nguyen, T., Siegmund, T., et al.: Crash analysis of a conceptual electric vehicle with a damage tolerant battery pack. Extreme Mech. Lett. 9, 371-378 (2016)

15. Mizuno, K., Wani, K., Yonezawa, H.: Vehicle crashworthiness in full and offset frontal impact tests. JSAE Rev. 24(2), 173-181 (2003)

16. Liu, Y.: Optimum design of straight thin-walled box section beams for crashworthiness analysis. Finite Elem. Anal. Des. 44, 139-147 (2008)

17. Wu, B., Xin, Y., Ye, S.: Improvement analysis of the SUV frame for crashworthiness reliability optimization. Mach. Des. Res. 24(01), 160-164 (2015) (in Chinese) 